\title{
THE CONTEMPORARY MOVEMENT IN FRENCH PHILOSOPHY.
}

RENAN AND TAINE addressed the general public. While served as vehicles for ideas which were destined to become popular, a number of works of a more specially philosophical nature, and therefore appealing to a far less numerous class of readers, have appeared in France, bearing witness to the speculative activity of the country.

At the first glance that we cast upon the latter half of the nineteenth century, we are struck with the extreme variety, or, more accurately speaking, with the isolation and fortuitous distribution of theories. There is no powerful and dominant school sufficiently representative of the spirit of the time to rally the great majority of thinking minds, as had been done by Cartesianism, by the philosophy of the Encyclopædists, and even by Eclecticism about the year 1830 Each philosopher, jealous of his independence, follows his own course. Many, out of dislike for quackery and oratorical philosophy, withdraw into a sort of disdainful privacy, which has its advantages as well as its drawbacks. It is certainly to be regretted that philosophical speculation should seem to confine itself within an "ivory tower," abstaining from intimate intercourse with contemporary life; it thus runs the risk of assuming a formal, narrow, scholastic character, and of bestowing much energy and skill upon problems of purely factitious interest. History shows that. this danger is far from imaginary. On the other hand, it is no less dangerous for philosophy to seek avowedly the immediate favor of 
the public; the reason for this is evident. The philosophers of whom we are speaking have at least escaped the latter peril. Remote from the crowd and unknown to it, unknown for some time even to all but specialists in their own line, there was nothing to disturb the elaboration of their doctrines.

It is also a noteworthy fact that they nearly all began by writing on the history of philosophy. In the eighteenth century, Kant remarked that, being entirely absorbed in his own system, he had no time to familiarise himself with those of others. In the second half of the nineteenth century, on the contrary, nearly every philosopher thinks himself bound, before producing a new system, to be thoroughly acquainted with the previous ones. The history of philosophy had, indeed, just been revived in France by Cousin, and, besides, there was a general increase of the feeling of historical solidarity. Was it not natural, therefore, that philosophy, as well as the other moral sciences, should feel the effect of it?

Thus it happens that, though there is not found in this period any theory which has given rise to a wide and powerful philosophical current, it remains possible to locate the various doctrines, either in the general course of some great pre-existing current, or at the junction of several.

Apart from eclecticism and positivism, it seems that we may distinguish four main currents :

First, a Kantian current, derived in part from Kant's theoretic philosophy, and in part from his moral philosophy;

Second, a metaphysical current, a reaction against positivism and against critical and relativist doctrines in general, proceeding from the great modern metaphysical systems, and more particularly from Leibniz and Schelling;

Third, an evolutionist current, clearly following Lamarck, Darwin, and Mr. Herbert Spencer;

Fourth and last, a current which may be termed separatist, and which, being more or less directly derived from Comte, is disposed to abandon the old conception of philosophy, and to organise scientific and positive psychology, ethics, and sociology. 
This, without counting a great many secondary currents and under-currents which we should be obliged to characterise, were not this sketch necessarily a very summary one.

Eclecticism is still the philosophy officially taught in France. This prerogative, which assures it a positive influence upon the intellectual development of the nation, is harmful to it in other respects. Being subject to considerations of a political rather than a philosophical nature, it has not been possible for the system either to develop or to rehabilitate itself. Eclecticism no longer investigates, it merely teaches, said one of its adversaries (M. Renouvier). Fortunately, intellectual originality never renounces its rights. Aside from M. Vacherot, who did not hesitate to part from the school in order to try to found a new spiritualistic system, there are M. Bouillier, who has written a conscientious history of the Cartesian philosophy, Bersot, the author of ingenious moral essays, and Caro, who produced brilliant critical studies. Frank published a philosophical dictionary to which all the best men of the school contributed; M. Lévéque has applied the principles of eclecticism to æsthetics.

Paul Janet has employed his clear and sound judgment in the consideration of the most various subjects. Not only did he develop the doctrine of eclecticism in his Morale, his Causes finales, but he has discussed contemporaneous questions in many works such as Le cerveau et la pensée, La crise contemporaine, and has made important contributions to the history of philosophy, such as: L'histoire des idées et des théories politiques, L'histoire de l'école St. Simonienne, and a biography of his master V. Cousin, in which he has established the truth on several important points. M. Janet has been a rare example of perfect fidelity to the doctrine he had adopted in his youth, united with a broad sympathy for all attempts to establish new theories. His respect for philosophical liberty, which he does not separate from other kinds of liberty, permits him to be at once extremely dogmatic and yet sincerely impartial towards his adversaries, the fiercest of whom have always been willing in the end to do him justice. 
"Eclectic spiritualism" had none the less to contend against an opposition growing in strength and number, which was more hostile to its method even than to its conclusions. M. Renouvier reproached it with having neither a clear and consistent method, nor sincerity, nor precision; with borrowing its dogmas "from theological traditions which have now become pure conventionalities," and with being afraid of logic. Other equally severe attacks have been repeatedly directed against it. Especially after the death of Cousin, eclecticism constantly lost ground. Indeed, more than one philosopher whose metaphysical convictions were not really very different from those of eclecticism, honestly felt compelled to combat it in order to establish his own views.

On the other hand, whilst the spirit of positivism was constantly gaining new influence and spreading by a thousand channels through the mass of the nation, the adherents of the system properly so called did not increase in numbers. The peculiar style and the extravagant pretensions of Auguste Comte's later works had done great injustice to the very essence of La philosophie positive, with the original text of which few people were acquainted. The schism in the school and the quarrels which ensued had also produced an unfortunate impression. Littre, the real standardbearer of the doctrine, although a dissenting disciple, was a scientist rather than a philosopher, and if he made clear Comte's copious and prolix thought, we must confess it was at the cost of its richness and depth. Orthodox positivists, under the guidance of M. Pierre Laffite, kept close within their church. The time had come for the revival of metaphysical speculation.

This revival, which had given tokens of its approach as early as the middle of the century, assumed various shapes according to the predominance in it of the spirit of dogmatic metaphysics, or of the influence of the Kantian criticism. The philosophy of $\mathrm{M}$. Ravaisson belongs to the first class, and is derived in various proportions from Aristotle, Leibniz, and Schelling. According to $M$. Ravaisson, all philosophical systems may be reduced to three types, which are so many points of view from which the truth is more or 
less thoroughly perceived. On the lowest stage are the empiric philosophies. They are blind to all that is not revealed to the senses. These systems are not false in their affirmations; but what they deny is infinitely more real than what they take to be the only reality. Above these, on an intermediate stage, rank the philosophies of the understanding, such as Stoicism and Kantism. They recognise, indeed, that the mind has its proper activity, but they believe it incapable of rising above certain insurmountable barriers, such as time, space, causality, and there they stop. Lastly, on the summit, are the systems of metaphysics which have understood that sentient and even discursive knowledge would not be possible did there not exist an intuition of the reason, in which real being, the absolute, reveals itself without any intermedium, and by which reason is united to the absolute as to the perfect principle of all existence, of all knowledge, of all beauty, and of all force. To this system are added a philosophy of nature which shows the eternal ascent of imperfect beings towards the all-perfect being who is both their cause and their end, and a philosophy of history which sees in religion and art revelations parallel to that of reason.

The philosophy of Secrétan, contemporary with that of M. Ravaisson, is also allied to Schelling's second system, but more closely. It has moral and religious tendencies. M. Secrétan's main effort was to reconcile and even to identify with the dogmas of his Christian belief the metaphysical conclusions which result from his speculation. He was a Protestant and accordingly enjoyed the liberty necessary to treat such questions. He speaks as a theologian no less than as a philosopher when he touches upon the formidable problems of the origin of the world, of the divine personality, and of the explanation of evil. His supreme principle is the idea of God's absolute liberty, which great metaphysicians, such as Descartes, had already affirmed before him. From it he infers the possibility of chance in the world and of liberty in man.

In the latter part of his life Secrétan had lost much of his interest in such a lofty and abstruse science of metaphysics. Not that he had ceased to believe it true; but he thought it less necessary. Duty, being manifested to the conscience as a categorical 
imperative, now seemed to him a sufficient revelation of the Absolute. Therefore, laying aside these speculative difficulties which are calculated to make even the most powerful minds dizzy, he directed his efforts to moral and social questions. He felt how serious are the problems set before all Europe by socialism, and sought the solution of these, not as an economist, but as a philosopher and a Christian. Yet it was chiefly his Philosophie de la liberte which exercised upon French thought a slow but deep and lasting influence. This influence is found more or less distinctly permeating the numerous philosophies of liberty which have appeared in the second half of the present century, and is particularly visible in M. Fouillée's teachings.

If Kant's philosophy met with little response in France in the first half of this century, it was not because it was unknown; on the contrary, even in the earlier years of the century we find it mentioned and criticised. But no one had stopped to investigate it thoroughly, either because many thought with Schelling and Hegel that it suffered from being over-subjective; or more probably because, as most eclectic philosophers said, its idealism seemed to end in a sort of scepticism. As Kant denies to human reason the capacity to solve metaphysical problems dogmatically, to demonstrate the existence of God and the immortality of the soul, he is in their eyes a sceptic. All the arguments against sceptics in general hold good against him, and there is no need of paying any further attention to him. So it happened that the first men who began afterwards to study the text of Kant felt as though they were making a discovery. Instead of a negative and sceptical system, they found one of the most powerful efforts ever made by the human mind to measure the scope of its own faculties and to reconcile the demands of science with those of morality. The effect of this discovery was not long delayed; it gave a new impulse to philosophical studies in France, and several original systems appeared, all drawing inspiration from Kant's ideas.

These were chiefly idealistic systems, as had been the case in Germany also. M. Lachelier, for instance, in seeking for the fun- 
damental principles of induction, came to the conclusion that a science of nature would be an impossibility if the laws of thought were not at the same time, as Kant maintained, the constitutive laws of nature. But for all that, M. Lachelier does not adopt the theory of space, time, and categories enunciated by Kant in the Critique of Pure Reason, which concedes to our science only a relative value, and denies to man the knowledge of things as they are in themselves. M. Lachelier, on the contrary, believes that there is a method, i. e., reflexion, by which our thought may contemplate and possess itself in its very essence, and that, having reached this point, it has attained to absolute being and has nothing to seek beyond itself. This was a singularly refined form of idealism, which goes beyond Kant and connects with Leibniz; sensible knowledge being conceived, after the fashion of Leibniz, as an obscure form of intellection. The concepts of space and time, instead of being imposed upon human knowledge, as in Kant's system, without our knowing how or why, are deduced from the very essence of thought by an effort of reflexion. Thus a purely idealistic doctrine is propounded, according to which "ideas are given before sensations and laws before facts." After being expounded in lectures given at the École Normale, and summed up in a vigorous and concise little book, this form of idealism had to struggle against the diffuse influence of positivism, and against the increased favor bestowed upon English empiricism. It aroused and maintained a taste for metaphysical speculation. Itself a product of Kant's critical method, it occasioned in its turn the production of new doctrines, which owed to it at least their initiative.

Such is the doctrine of M. Boutroux, who, in his remarkably profound book, La contingence des lois de la nature, asked whether the laws of nature were absolutely immutable, or whether they might not admit of some sort of contingency affording scope for the free activity of rational beings. He proved that an absolutely rigorous necessity is inconceivable to our minds; then from a scientific point of view he pointed out further that even the laws of science do not imply the absolute necessitarianism which has been claimed for them. As we consider more complex and richer orders 
of reality, after the world of inanimate nature the world of life, after the world of life the world of thought and morality, the degree of contingency permitted by the laws of phenomena also becomes more apparent, and liberty at last asserts its presence in man's consciousness. That which is subject to measurement and calculation, which presents an aspect of perfect regularity, uniformity, and necessity, is but the surface of things; at bottom Leibniz's principle of the indiscernible is true; there never are two entirely identical beings or phenomena; no general formula is adequate to the ever-changing spontaneity of reality. But M. Boutroux, who has a thorough knowledge of the great systems of the past, and has thoroughly investigated their evolution, preserves a critical attitude towards metaphysical principles instead of merely drawing these inferences from them. He is alert to the postulates and results of positive sciences, and respectful of experience, even while examining and interpreting it. $\mathrm{He}$ is determined to sacrifice no portion of reality, and to give their due share to facts as well as to ideas, to science as well as to morals.

From Kant again, and, in a smaller degree, from Hume and from A. Comte, is derived the philosophy of M. Renouvier. His Essais de critique generale marks an era in the history of French philosophy of the nineteenth century. Like A. Comte and several other vigorous thinkers of the time, M. Renouvier had received his training in the study of mathematical sciences at the École Polytechnique. These sciences, and also his convictions concerning social problems, induced M. Renouvier to study the philosophical questions on which all others depend. He could not be satisfied with the doctrines which were popular in his youth. We have heard how he condemned eclecticism with the utmost severity. $\mathrm{He}$ reproaches positivism with its empiric dogmatism which will not take the trouble even to justify itself, with its presumption in attempting to "organise science and religion," and to solve in a negative way the question of "possibilities which ought to be the prerogative of free belief." But he accepts this positivist principle, viz., that our knowledge pertains only to phenomena and the laws 
of phenomena: a principle, moreover, in accordance with the results of the philosophy of Hume and Kant.

M. Renouvier gave to his doctrine the name of Criticisme. It manifests its Kantian origin, both in basing the solution of philosophical problems on a previous criticism of the human understanding, and in its way of stating the moral problem. But M. Renouvier radically modifies Kant's theory of knowledge. True, he also states that time and space are not realities in themselves, and that our thought operates by means of categories (of which M. Renouvier furthermore draws up a new list). True, he thence infers, again following Kant, that we know nothing but phenomena, and that in every cognition the part of the mind which knows is inseparable from that of the object which is known. But, beyond phenomena, Kant admitted a world of "pure objects" (Dinge an sich) inaccessible to our knowledge, and yet the foundation of the reality of phenomena. In these "pure objects," in these "noumena," M. Renouvier sees but a last remnant of the "substances" of the old metaphysics so aptly criticised by Hume and which Kant retained only at the cost of self-contradiction. In accord on this point with nearly all the neo-Kantians, M. Renouvier rejects these "pure objects" which Kant himself admitted to be absolutely unknowable. He holds that there is no reality but that given in consciousness.

For a while $M$. Renouvier inclined towards Hegelianism, and thought that, though to our finite understanding two contradictory propositions exclude each other, from an absolute point of view they may be reconciled or even support each other. But he soon assumed the contrary position and afterwards made it a rule to consider as false whatever he found incompatible with the supreme logical law of our thought, called the principle of contradiction; and he constructed the whole of his philosophy in accordance with the rigorous application of this rule.

For instance, he owed to it the solution of Kant's antinomies; or, rather, he showed that, had Kant observed this rule, he would not have formulated his antinomies. For one ought not to ask whether space is finite or infinite, whether the world had a begin- 
ning or not. To say that space is infinite, or that the world had no beginning, is equivalent to admitting that an infinite number is possible and even real. Now, according to M. Renouvier, the realisation of infinite number is an absurdity, a contradiction in terms; therefore such a number does not exist, and therefore we must admit that space is not infinite, that the world had a beginning, that the ascending series of causes has a first term, and consequently that chance and liberty both have a place in the world of phenomena. Add to this the exclusion of the idea of substance,which, if once tolerated in a system, leads inevitably to unity of substance, that is, to pantheism and fatalism, -and you have the elements of a system at once idealistic and phenomenalistic, which undertakes to establish, as conclusions of critical study, man's liberty and personality, an order in nature compatible with contingency, and the existence of an author (M. Renouvier for a long time said, of several authors) of the universe.

Does Criticisme then, after a long and toilsome circuit, simply come back to the theses of the old dogmatic metaphysics? It would be unfair to say so, though the differences are not so great as one would at first imagine. But the road followed by Criticisme is a new one, and M. Renouvier flattered himself with occupying a position that the old metaphysics had never reached. For want of having made a criticism of the human mind, for want of having acknowledged that we know phenomena only, for want of having understood that certitude is but a phase of belief and that liberty is implied in every affirmation, these "substantialistic" doctrines were inevitably condemned, by the internal logic of their own principles, to deny, in spite of themselves, man's liberty and the distinction between God and the world. Phenomenalistic Criticisme alone can be logical in affirming these things and in affirming them freely.

With M. Renouvier, even more decidedly than with Kant, the supreme interest is that of action, and therefore the centre of gravity of philosophy lies in morals. In man's conscience is to be found the only really fixed point, the only belief unassailed by doubt, the revelation of the absolute, on which, for us, all the rest depends, and which itself depends on nothing else. The ethics of 
duty is admirably emphasised in M. Renouvier's works. It is the ever-present inspiration and the very soul and centre of his doctrine. It is this which has chiefly contributed to give it a firm hold on many of our contemporaries.

Social ethics is treated much more fully in M. Renouvier than in Kant, as might be expected from a former admirer of St. Simon and Fourier. But, while rightly recognising the fact of social interdependency and its consequences, he vigorously opposes the positivist theory of progress, and, in a general vay, all philosophy of history which tends to fatalism. He regards the complete subordination of the individual to society as a baleful thing. His only hope for the future is from the free and deliberate efforts of the individual. His social ideal is above all one of justice.

After combating for a long time with passionate earnestness the philosophy officially taught in France, Criticisme at last made its way into that very official teaching. In more than one case it triumphed now over eclecticism, which was decidedly out of favor, and again over even the dogmatic idealistic systems. Many university professors in our days adhere to the philosophy of $M$. Renouvier and of his faithful disciples MM. Pillon and Dauriac. The summons had been given more than fifteen years ago by M. Brochard in his work entitled De l'erreur. Criticisme is clearly the form of Neo-Kantism which has been best acclimated in this country. Whatever may be the future of the system, it has at least manifested vigorous life, and effectually contributed to restore the unprejudiced study of philosophy in France.

Opposed in many respects to $M$. Renouvier's philosophy, there arose another system, the success of which was no less considerable: the system of M. Fouillee, an extremely prolific writer, endowed with inventive imagination and wonderful dialectical resources, his style as easy as that of M. Renouvier is laborious. M. Fouillee has already presented to the public a long series of works, some historical, some dogmatic, and others critical and controversial, in which his doctrines have gradually taken shape. His first purpose seemed to be to substitute for eclecticism a philosoph- 
ical synthesis at once very comprehensive and very consistent. Being remarkably well informed on the history of systems and quick at discovering how the constitutive principles of the chief ones among these may adapt themselves to one another, or cover or supplement one another, he sought a higher point of view whence he might survey all the systems he meant to reconcile. He had studied profoundly the modern philosophies of liberty, but he was no less indebted to the great systems of antiquity and particularly to the philosophy of Plato, which had been the subject of his first work. One may believe that he found a model for his own system in this broad theory of ideas, into which Plato could introduce all the essential parts of the chief Greek philosophies previous to his own without impairing its harmonious unity.

M. Fouillee acknowledges the advance made by the Kantian criticism over the former systems of metaphysics; but he does not hesitate to critisise the philosophy of Kant himself, and refuses to accept either his ethics or his theory of knowledge. The leading idea of his own system is the hypothesis of the idées-forces. On it he founded his psychology, his ethics, his general theory of nature and society, and lastly a doctrine of metaphysics based on experience.

An idea, according to him, is not a mere representation, that is, a sort of mental reproduction of a real or supposed object outside itself; an idea is at the same time a force, working for its own realisation. For instance, liberty is not a reality given objectively, of which we have an idea because we perceive it; but, on the contrary, it is because we have an idea of our own liberty, because we believe in it, because we adapt our conduct to this belief, that we are actually free, and that our freedom is effectual in the world of phenomena. Our ideas and feelings are conditions of real internal change, and consequently factors in mental evolution, not mere signs of an evolution wrought independently of them by exclusively physical causes. Furthermore, every internal change, being inseparable from an external change or motion, produces effects upon the external world, so that ideas, having acted inwardly, at the same time find outward expression with all the resulting conse- 
quences. Thus the internal and the external efficacy of mental states are inseparable, because of the fundamental unity between the physical and the mental.

The idea is therefore inseparable from action, that is to say, from motion. "It is a form, not only of thought, but of volition; or rather, it is no longer a form, but an act, conscious of its own direction, quality, and intensity." This indissoluble union between thought and action is the all-important psychological law summed up in the term idée-force. Not that ideas intervene physically so as to interfere with the universal mechanism. This would represent the idee-force as an object endowed with a certain amount of persistent energy. Nothing is further from M. Fouilleée's thought. $\mathrm{He}$ does not conceive ideas as being apart from one another and endowed each with its individual power. Every state of consciousness is the resultant of a prodigious number of actions and reactions between us and the exterior world, while its correlative is the sum of our cerebrations at any given moment.

From this conception M. Fouillee easily derives a criticism of the theories put forward by spiritualism and materialism on the relation between the soul and the body, then a criticism of the notions of soul and body themselves, and finally the elements of a general theory of the universe, in which, the world of motions being conceived as inseparable from the world of ideas, there is established a real monism, the monism of idtes-forces, superior both to materialism and to idealism. It is easy to understand how the same principle is applicable to the philosophy of history and of law, and to the solution of sociological questions, which were always of special interest to $\mathrm{M}$. Fouillee. In all these matters he can stand above the empiricist and rationalistic systems which indefinitely oppose each other without either of them ever gaining a decisive victory; he shows everywhere, to use Leibniz's expression, that they are right in their affirmations and wrong in their negations. His doctrine, in short, deals fairly with them all in criticising them all, and yet remains different from each of them even at the moment when he identifies it with some aspect of his own theory. This broad spirit of conciliation did not sap M. Fouillée's vigor, 
and we need only read his Critique des systemes de morale contemporaines to feel sure that the weak point of a system cannot easily escape him.

M. Fouillée's philosophy is certainly one of those which best represent the collective aspirations and intellectual needs of the present time. It contains every element of modern thought : the critical spirit which recognises no barriers and claims a right, despite the school of Criticisme, to test the very idea of duty; a tendency to adopt the historical and evolutionary point of view; respect for positive science; a taste for social problems; an effort to construct a positive psychology, and to found a science of metaphysics that shall sincerely take into account the modern theories of knowledge. The greatness and inherent interest of such an effort is evident to all eyes; time will show whether a reconciliation between opposite systems is not often achieved by M. Fouillée at the expense of the integrity of the system which effects the reconciliation, and whether the framework of his philosophy, the conception of the idees-forces, is strong enough to support the weight of such a comprehensive doctrine.

We must not separate M. Fouillée from his nephew Guyau, whose genius, prematurely lost to philosophy, he celebrated in touching terms. Guyau, who died at thirty-three, left works sufficiently complete to demonstrate clearly the originality of his mind. It was not his ambition to attempt a conception of the whole universe; he feared that a metaphysical system, of whatever sort, would always be lacking in stability. His efforts were especially directed towards the moral, asthetic, social and religious problems which confront man's conscience in our times, the old solutions of which are seldom satisfactory to any conscience which is honest with itself. Guyau thought that a new solution might be sought in sociology. "Guyau's leading idea," said M. Fouillée, " is that of life as the principle common to art, ethics, and religion. According to him-and this is the generative conception of his whole system-life, rightly understood, involves, in its very intensity, a principle of natural expansion, fruitfulness, and generosity. From this he concluded that normal life naturally reconciles in it- 
self the individual and the social point of view." By showing this social aspect of individual life, we might establish at the same time both art and morals on a basis which should henceforth be solid. And Guyau hopes for the creation, in the twentieth century, of a social science based on a scientific psychology, the first rudiments of which we behold in our own time. The influence of A. Comte is obvious here; it also appears elsewhere in Guyau's thought, for instance in his conception of the immortality of the soul. His works nevertheless bear a strongly marked individual character, due both to his passionate earnestness of thought and to the charm of his style.

Few doctrines in the period we are considering contain as many keen, deep, and original views as the works of Cournot. Yet his fame has not extended beyond a very limited circle. There was indeed nothing in his style capable of attracting the general public; yet more than one of those who attract the attention of the public have read Cournot and availed themselves of their reading. A prudent, methodical mind, well trained in the practice of the sciences, averse to all hasty generalisation, Cournot tried to determine what we may know of the foundations of our knowledge. Most philosophers have sought the solution of the problem in the analysis of our faculty of knowledge; Cournot followed another method. He carefully investigated each of the sciences which the human intellect has built up in order to gain a better knowledge of the universe and to exercise upon it practical influence; he analysed the principles on which these sciences depended for the establishment of their laws, and sought to discover whether it were possible by bringing together the principles and methods of the different sciences to obtain a group of fundamental ideas. This group will then constitute his philosophy.

Three ideas are of paramount importance in this doctrine, which shuns all a priori deductions and constitutes a system only in so far as experience warrants: these are the ideas of order, chance, and probability. Order exists in the universe. It is the regular recurrence of the series of phenomena that makes it pos- 
sible for us to acquire a knowledge of their laws, and the faculty of putting the universal order into an intelligible form is what is called in us reason. But this order is not such that we can deduce the laws of phenomena by means of an abstract action of the mind. Induction is necessary to arrive at these laws, and induction does not convey absolute certitude, but only probability, which may be practically equivalent to certitude, but leaves room theoretically for contrary chances. For chance is not a word invented to conceal our ignorance, as has been claimed by philosophers; it is a positive factor in the sum total of reality; it comprises all that results from the concurrence of independent causes. Its part in history is undeniable; it is no less so in the evolution of our universe, which may be considered as a sort of history. But, whatever be the actual part played by chance, it is a fact that the various series of phenomena occur in a regular way, and that order exists. The conclusion we are to derive from this must not be more absolute than the principle itself; this order comprises possible irregularities and exceptions; outside the domain of mathematics, we must always make a principle of reserving a place for what may appear without our being able to foresee it. Therefore no science of real phenomena can claim absolute certitude, moral sciences less than any other, and philosophy still less than ethics. Philosophy is merely an attempt to connect what has been taught us by the study of different classes of phenomena, and to conceive order as universal. The controversies of philosophers show sufficiently that several conceptions of this kind are equally possible. Philosophy proceeds naturally from man's reflexion upon science; but it is not itself a science.

This doctrine, clearly akin to positivism and Criticisme, is nevertheless separate and distinct from them, and even emphasises some of their defects. It warns us against the too often rash affirmations and conjectures in which our reason indulges. But can a philosophy exist that dares not assert itself as a philosophy? May it not be to its extreme cautiousness that Cournot's doctrine owes the relative obscurity in which, despite its rare value, it has remained? 
A philosophical doctrine can be but a great hypothesis: this may be a weakness, but it is also the only reason for its existence.

We are thus brought to the large category of thinkers who believed that such a hypothesis was henceforth impossible, and who gave up all attempts to seek for a total and absolute explanation of the universe. Therefore they abandon the pursuit of essences, causes, and ends. They are still philosophers, but have renounced the name of metaphysician. This positivistic tendency is found in the most various domains.

We must first mention men of science, such as the physiologist Claude Bernard, and the chemist M. Berthelot, who, while enriching science with valuable discoveries, have also reflected upon the nature and scope of science itself. Independently of his interesting observations on the experimental method in general, Claude Bernard has endeavored to determine exactly the object of physiological science, and his conclusions agree most strikingly with what Auguste Comte has said on biological philosophy. On the one hand, Claude Bernard disencumbers physiology from the last remnants of metaphysics which were still clinging to it. Science, here as elsewhere, seeks only to know phenomena and their laws. It has nothing to do with a so-called "vital principle" to "explain" those phenomena, which, considered singly, are never other than physical and chemical phenomena, which are identical in living and lifeless bodies. But, on the other hand, Claude Bernard does not mean to "reduce" physiology to physics and chemistry. $\mathrm{He}$ is fully aware that this would be equivalent, as Auguste Comte said, to explaining the superior by the inferior. He shows that life has something specific and irreducible to a physical and chemical mechanism. He emphasises the part played by the "dominating idea," which seems to preside over the evolution of the living being, and the necessity that the biologist who wishes to understand one phenomenon should connect it with all the others that take place at the same time, and even with those which shaped the past life of the creature. In short, Claude Bernard's chief object is to establish the positive character of physiology and its connexion with the 
other and older positive sciences, yet without infringing upon its separate original and irreducible character.

M. Berthelot, being equally versed in chemistry and in the history of its beginnings, arrived also at general views not very different from those of the positive philosophy. He thinks that the progress of science will gradually make a theological and metaphysical attitude untenable. As minds become familiar with the knowledge of natural laws, they become incapable of harboring superstitions and arbitrary hypotheses. In this $\mathrm{M}$. Berthelot shares the convictions and hopes of the philosophers and scientific men of the eighteenth century. He shows what great changes have already been wrought by the influence of the positive sciences; and yet nearly all of these sciences are just beginning their career, and their influence has only begun to triumph over violent and desperate opposition. What then may we not expect from the future, when these sciences shall hold undisputed sway, and shall have made discoveries beyond all our present dreams, which will probably transform both the conditions of social life and the traditional rules of morality? For the moral sciences are destined to become positive, after all others, it is true, but no less surely.

This last stage seems to have been attained by psychology in our days. M. Ribot, casting aside the semi-literary and semimetaphysical psychology of the eclectic school, initiated the study of scientific psychology in France. He is not a positivist, inasmuch, as he does not, like Comte, regard metaphysical investigations as useless and even injurious; he has written an excellent little book on Schopenhauer, and wishes to leave all questions open. But his conception of psychology is in perfect conformity with the positivist spirit. He defines it as a science of facts, the sole object of which is the search for the laws concerning these facts. The psychologist needs not choose between materialism and spiritualism, or decide whether it is the soul that acts upon the body or the body upon the soul: this is the business of the metaphysician.

The psychologist knows the facts from inward observation, and studies them according to the objective method. He does not regard psychical facts as constituting by themselves an order of real- 
ities independent of all others; on the contrary, though careful not to say that facts of consciousness are but a phase of physiological facts (an unverifiable and metaphysical assertion which oversteps the limits of his science), he studies nevertheless, the facts of consciousness, as far as possible, only for the purpose of seeking for and establishing their association with the physical facts of the nervous system. Adding example to precept, M. Ribot has published a number of books in which the keenest psychologic faculty is combined with a strictly scientific method. In each of his works he endeavors to reduce some special laws to one general psychological law which shall furnish the reason for a great many facts. He holds that psychologic science leads to theories which are at least provisionally satisfactory, without being absolutely demonstrated, similar in this respect to the great hypotheses of physics. Following M. Ribot came a whole school of young psychologists who abstain from even such theories, and who apply all their energies to laboratory investigations of a very special and often minute nature. There remains nothing in common between psychology understood in this way and what the eclecticists or Scotchmen called by that name.

Sociology is far from having assumed such a decidedly positivist form. It still retains more than one of the features which according to Comte mark a science still in the metaphysical stage. Works on sociology are still chiefly devoted to defending the legitimacy, the object or the method of this science. Those who treat of it rarely take up the science at the point where their predecessors had left it; each of them contributes his own definition of social facts, upsets the edifice raised by the others, and goes about building a new one. There is nothing surprising in this state of sociology. Social phenomena being the most complex of all, sociology must necessarily be the last science to reach the positive stage, and among the very numerous attempts made to organise it, some will certainly be made use of by the science of the future. Such are the works of MM. Espinas, Durkheim, and Tarde, to cite only a few names. M. Espinas comes first in order of date, with a fine study on Les societes animales. M. Durkheim, in his Division du 
travail social and in his Règles de la methode sociologique, endeavored to treat the facts of moral life after the method used in the positive sciences, that is, not only to observe them carefully, to describe and classify them, but to find out in what way they are capable of becoming objects of scientific study, and, to this end, to discover in them some objective element which will admit of exact determination, or, if possible, of measurement. If the definition of the "sociological fact" were sufficiently exact, the greatest diffculty would be overcome, and social science could then progress rapidly. Like other positive sciences, it would give man "foresight and power."

M. Tarde feels much less strongly than M. Durkheim the need of making sociological investigations rigorously scientific. $\mathrm{He}$ studies social phenomena now as a psychologist, now as a historian, and again as a philosopher; the comparative method, broadly and freely applied, being his favorite procedure. He has given us profound and thorough criticism of Italian theories of criminality, particularly those of Lombroso, and his own Philosophie penale contains many views which are original, comprehensive, and often suggestive. The same thing may be said of his Lois de l'imitation and of most of his other works. Amid the sometimes crowded and rather desultory abundance of his ideas, there is found a considerable number of more systematic æsthetic and even metaphysical convictions, which now and then make themselves manifest, and give unity to the work.

We are very far from having given even a summary idea of the active contemporary philosophical movement in France. How many interesting works we are obliged to pass over in silence! Let us at least mention, in psychology, under its various forms : Fr. Paulhan (L'activité mentale, Les phénomènes affectifs, etc.), Egger (La parole intérieure), Pierre Janet (L'automatisme psychologique), Féré (Sensation et mouvement), Binet (La psychologie du raisonnement, L'année psychologique), H. Bergson (Essai sur les données immédiates de la conscience, Matière et mémoire); in metaphysics, MM. Evellin (De l'infini) and Rauh (Le fondement métaphysique de la morale); in logic, MM. Liard (Des dé- 
finitions géométriques et des définitions empiriques, etc.), Brochard (De l'erreur, Les sceptiques grecs), Naville (La logique de l'hypothèse); in moral and religious philosophy, MM. Marion (La solidarité morale), Ollé-Laprune (La certitude morale, Le prix de la vie, etc.), and Sabatier (Essai d'une philosophie de la religion); in sociology, MM. de Roberty (La sociologie, Auguste Comte et Herbert Spencer, etc.), De Greef (Les lois sociologiques, Le transformisme social, etc.), Lacombe (Les lois de l'histoire), Henry Michel (L'idée de l'etat); in the philosophy of the sciences, MM. Delbœuf (Le sommeil et les rêves, La matière brute et la matière vivante), Hannequin (Essai sur l'hypothèse des atomes), Couturat (De l'infini mathématique); in esthetics, MM. Sully-Prudhomme (De l'expression dans les beaux arts), and Séailles (Essai sur le génie dans l'art); in the history of philosophy, MM. Adam (La philosophie en France au XIXe siecle), Tannery (Pour l'histoire de la science hellène), Lyon (L'idéalisme en Angleterre, La philosophie de Hobbes), Delbos (Le problème moral dans la philosophie de Spinoza), Denis (Histoire des idées et des théories morales dans l'antiquite), and so many others whom we regret not having the space to mention.

The very number of all those we should have cited will be our excuse. True, this philosophical activity, of which the Bibliothèque de philosophie contemporaine gives so many tokens, seems at the same time to be quite desultory and fragmentary. But perhaps we overrate the diversity of the philosophical tendencies of the present time. Perhaps we are laboring under an optical illusion inevitable to those who try to take a general view of contemporary events. Probably many an important point of resemblance between doctrines escapes us, because the very spirit of our time, with which we are all imbued, is expressed in these resemblances, while, on the other hand, we take too much notice of secondary differences. The historian, in the next century, will discern the due proportions. $\mathrm{He}$ will at least recognise, in these diverse doctrines, a common effort to adapt traditional philosophy to the new conditions imposed upon it by the development of natural, historical, and social sciences.

Paris, France.

L. LEVY-BRUHL. 